\section{Brazilian women avoiding pregnancy during Zika epidemic}

Brazil now has confirmed 1845 cases of Congenital Zika syndrome in babies (TORCHZ) in a group of 9091 suspected cases. ${ }^{1}$ It is estimated that 174003 Brazilians have been infected with Zika, although the Ministry of Health has not published any updated surveillance data since early July $2016 .{ }^{2}$ To understand if and how the epidemic has impacted reproductive health practices, we conducted a national survey in June 2016 using mixed methods. We used a face-to-face questionnaire to collect sociodemographic and opinion and practices data about reproductive health and pregnancy and a secret ballot box to gather information related to abortion experiences. We collected data from a nationally representative sample of 2002 urban Brazilian women between the ages of 18-39 years and literate, thereby corresponding to $83 \%$ of the total female population (with a confidence interval of $2 \%$ ).

The results provide an important first glimpse into how the Zika epidemic has shaped pregnancy intentions among women in Brazil. A large proportion $(56 \%)$ of women reported that they had avoided (or tried to avoid) pregnancy because of the Zika epidemic. In contrast, $27 \%$ of women reported that they had not tried to avoid pregnancy because of the Zika epidemic and $16 \%$ reported that they had not been planning to get pregnant, regardless of the Zika epidemic. A higher proportion of Northeastern women $(66 \%)$ than Southern women $(46 \%)$ reported trying to avoid pregnancy - which likely reflects the fact that epidemic has been more concentrated in Northeastern Brazil. There were no significant differences among the main religious groups: $58 \%$ of Catholic women and 55\% of Evangelic women reported having avoided pregnancy because of the Zika epidemic. Black (64\%) and Brown (56\%) women were more likely to report avoiding pregnancy than White women (51\%), which also likely reflects the disproportionate impact of the epidemic among the most vulnerable racial groups.

In our opinion, Brazil must urgently re-evaluate its reproductive health policies to ensure better access to contraception information and methods, including a wider range of contraceptive methods, such as long-acting reversible contraception, which are scarce (copper intrauterine device) or not available (hormonal implants) via public health services. As indicated by the high proportion of women who avoided pregnancy because of Zika, the Brazilian government must place reproductive health concerns at the centre of its response, including reviewing its continued criminalisation of abortion.

\section{Debora Diniz, PhD}

Professor, University of Brasília/Anis, Instituto de Bioética, Direitos Humanos e Gênero, Brasília, DF, Brazil; d.diniz@anis.org.br

\section{Marcelo Medeiros, PhD}

Professor, University of Brasília/IPEA, Instituto de Pesquisas Econômicas Aplicadas, Braślia, DF, Brazil; marcelo.medeiros.cs@gmail.com

\section{Alberto Madeiro*, PhD}

Professor, Research Center and Extension Center in Women's Health/Piauí State University, Teresina, PI, Brazil; madeiro@uol.com.br
* Corresponding author

Competing interests None declared.

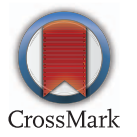

J Fam Plann Reprod Health Care 2017;43:80. doi:10.1136/jprhc-2016-101678

\section{REFERENCES}

1 Ministério da Saúde, Centro de Operações de Emergências em Saúde Pública sobre Microcefalias, Brasil. Informe Epidemiológico $\mathrm{N}^{\circ} 40$ - Semana Epidemiológica (SE) 33/2016 (14/08/2016 a 20/08/2016). Monitoramento dos casos de microcefalia no Brasil [online report]. http://combateaedes.saude.gov.br/ images/sala-de-situacao/ informe_microcefalia_epidemiologico40.pdf accessed 19 September 2016].

2 Ministério da Saúde, Secretaria de Vigilância em Saúde, Brasil. Boletim Epidemiológico $\mathrm{N}^{\circ}$ 31 - Monitoramento dos casos de dengue, febre de chikungunya e febre pelo vírus Zika até a Semana Epidemiológica 27, 2016 [online report]. http://combateaedes.saude.gov.br/ images/sala-de-situacao/2016-Dengue_ Zika_Chikungunya-SE27.pdf [accessed 19 September 2016]. 